\title{
Origin of the Black Shank Resistance Gene, $P h$, in Tobacco Cultivar Coker 371-Gold
}

\author{
E. S. Johnson, M. F. Wolff, and E. A. Wernsman, Crop Science Department, Campus Box 7620, North Carolina \\ State University, Raleigh, NC 27695-7620; W. R. Atchley, Department of Genetics, Campus Box 7614, North \\ Carolina State University, Raleigh, NC 27695-7614; and H. D. Shew, Department of Plant Pathology, Campus Box \\ 7616, North Carolina State University, Raleigh, NC 27695-7616
}

\begin{abstract}
Johnson, E. S., Wolff, M. F., Wernsman, E. A., Atchley, W. R., and Shew, H. D. 2002. Origin of the black shank resistance gene, $P h$, in tobacco cultivar Coker 371-Gold. Plant Dis. 86:10801084 .

Flue-cured tobacco (Nicotiana tabacum) cultivar Coker 371-Gold (C 371-G) possesses a dominant gene, $P h$, that confers high resistance to black shank disease, caused by race 0 of the soilborne pathogen Phytophthora parasitica var. nicotianae. The origin of this gene is unknown. Breeding lines homozygous for the $P h$ gene were hybridized with NC 1071 and L8, flue-cured and burley genotypes known to possess qualitative resistance genes from Nicotiana plumbaginifolia and $N$. longiflora, respectively. The $\mathrm{F}_{1}$ hybrids were out-crossed to susceptible testers and the progenies evaluated in field black shank nurseries and in greenhouse disease tests with $P$. parasitica var. nicotianae race 0 . Results showed that $P h$ was allelic to $P h p$ from N. plumbaginifolia in NC 1071. Testcross populations of hybrids between burley lines homozygous for $P h$ and L8, possessing Phl from N. longiflora, showed that $P h$ and $P h l$ integrated into the same tobacco chromosome during interspecific transfer. Nevertheless, the two loci were estimated to be $3 \mathrm{cM}$ apart. Random amplified polymorphic DNA (RAPD) analyses of the testcross progenies confirmed that recombination between the two loci was occurring. Forty-eight RAPD markers linked to $P h$ in doubled haploid lines were used in cluster analyses with multiple accessions of $N$. longiflora and N. plumbaginifolia, breeding lines L8, NC 1071, and DH92-2770-40, and cultivars K 326, Hicks, and C 371-G. A cladogram or region tree confirmed the data obtained from field and greenhouse trials, that $P h$, transferred from C 371-G to DH92-2770-40, and Php in NC 1071 were allelic and originated from N. plumbaginifolia.
\end{abstract}

Additional keywords: disease resistance genes, gene phylogeny

Black shank disease of tobacco is caused by the hemibiotrophic oomycete Phytophthora parasitica var. nicotianae (Breda de Haan) Tucker, which attacks tobacco roots, stems, and leaves at any stage of development. Disease development is rapid under conditions of warm temperatures and high humidity (16). Annually, 1 to $2 \%$ of the flue-cured tobacco crop is lost to black shank in North Carolina, and this results in millions of dollars in lost revenue.

Three physiological races of $P$. parasitica var. nicotianae are present in the United States. The most common strain, race 0 , is defined as being nonpathogenic on Nicotiana plumbaginifolia Viv. (1). Race 1 is pathogenic on N. plumbaginifolia, but is less fit than race 0 and occurs under intense selection pressure resulting from continuous cultivation of race 0 resistant cultivars (2). Races 2 and 3 and

Corresponding author: E. S. Johnson

E-mail: lizzjohnson@hotmail.com

Accepted for publication 21 May 2002.

Publication no. D-2002-0820-01R

(C) 2002 The American Phytopathological Society isolate 63 of $P$. parasitica var. nicotianae $(18,20,24)$ have been reported in South Africa, Connecticut, and the Hunsur tract in Karnataka, India, respectively.

Both oligogenic and monogenic resistance sources to $P$. parasitica var. nicotianae are known in tobacco. In 1931, Tisdale transferred oligogenic black shank resistance to cigar cultivar Florida 301 (Fla 301). This resistance source confers partial resistance to both race 0 and race 1 of $P$. parasitica var. nicotianae (27). Initially, Fla 301 resistance was the only source available to tobacco breeders, and it was used to develop all black shank-resistant flue-cured and burley cultivars in the United States up to 1964. As such, $71 \%$ of all tobacco cultivars released since 1964 also have Coker 139 and Hicks in their pedigrees (5). Severe losses in tobacco cultivars with a high level of Fla 301 resistance have been documented in plants under drought stress (26). This prompted the search for more reliable sources of black shank resistance. Consequently, dominant, monogenic resistance from $N$. plumbaginifolia $(1,7)$ and Nicotiana longiflora Cav. (26) were introgressed into tobacco breeding lines.

Segregation analyses on the root response of $N$. tabacum lines that contain dominant monogenic interspecific sources of black shank resistance have been ongoing, and conflicting results have been reported. In 1962, transfer of two types of black shank resistance sources from $N$. plumbaginifolia was reported. Type 0 resistance was conferred by a single dominant factor and was only effective against race 0 (1). Type 0,1 resistance was effective against both race 0 and race 1 of $P$. parasitica var. nicotianae (1) and could have been a Fla 301 type seed contaminant. In 1970, all accessions of $N$. longiflora tested were reported to be resistant to both race 0 and race 1 of $P$. parasitica var. nicotianae, whereas $N$. plumbaginifolia had high resistance to race 0 only (15). In 1971, no segregation for black shank resistance in $\mathrm{F}_{2}$ populations of $N$. longiflora $\times N$. plumbaginifolia was observed, and the authors concluded that the two sources of black shank resistance were homologous (8).

The flue-cured tobacco cultivar Coker 371-Gold (C 371-G), released in 1986, possessed the highest level of black shank resistance observed among U.S. flue-cured cultivars at that time. The origin of the resistance genes in this cultivar was unknown. Black shank resistance in C 371-G was reported to be similar to that of $\mathrm{NC}$ 1071, a breeding line with black shank resistance derived from $N$. plumbaginifolia (9). Black shank resistance in C 371-G is derived from a single dominant gene, designated $P h$, pyramided upon the Fla 301 quantitative genetic resistance (6).

Breeding lines NC 1071 and L8 have dominant monogenic black shank resistance derived from $N$. plumbaginifolia and $N$. longiflora, respectively $(12,26)$. Testcross populations from $\mathrm{F}_{1}$ hybrids between breeding lines homozygous for $\mathrm{Ph}$ and lines with known sources of dominant monogenic black shank resistance from $N$. plumbaginifolia and $N$. longiflora are suitable to study the allelic relationships among these black shank resistance sources. The objective of this study was to determine if $P h$ from C 371-Gold was allelic to the dominant resistance genes from $N$. plumbaginifolia and/or $N$. longiflora.

\section{MATERIALS AND METHODS}

Plant materials. The $P h$ gene was transferred from flue-cured cultivar C 371$\mathrm{G}$ to a burley tobacco population through 
the production of a three-way hybrid involving two black shank-susceptible burley breeding lines, doubled haploid (DH) 408 and DH 410. DH 408 was hybridized with $C$ 371-G, and the $F_{1}$ hybrid was crossed to DH 410. Twenty-six plants possessing the burley phenotype were identified from the segregating three-way cross and intercrossed at random to produce 13 full-sib families. Equal numbers of seeds from each cross were combined to form a random-mated burley population segregating for $P h$. Following three cycles of mass selection for black shank resistance in a field disease nursery, resistant inbred lines were produced (E. A. Wernsman, unpublished data). The $\mathrm{S}_{4}$ line, TG 593-13, known to be homozygous for $P h$, was used in this study.

To determine if $P h$ and the dominant monogenic black shank resistance gene in $N$. longiflora (designated $P h l$ in this paper) are allelic, TG 593-13 was hybridized with L8. Testcross progenies were produced by crossing the $\mathrm{F}_{1}$ hybrid $(P h / P h l)$ to the black shank-susceptible burley cultivar KY 14.

The $\mathrm{K}$ 326-derived $\mathrm{BC}_{1} \mathrm{~F}_{1}$ line $\mathrm{DH} 92$ 2770-40, possessing $P h$, was hybridized with NC 1071 to determine if $P h$ and the dominant black shank resistance gene in NC 1071 derived from N. plumbaginifolia (designated $P h p$ in this paper) are allelic. The $\mathrm{F}_{1}$ hybrid $P h / P h p$ was crossed as the female parent with black shank-susceptible tester DH94-1577-1 to produce the testcross progeny.

Field evaluation of the $P h / P h l$ and Ph/Php testcross progenies in black shank nurseries. A sample of $440 \mathrm{Ph} / \mathrm{Phl}$ testcross progenies from the cross [TG $593-13 \times$ L8] $\times \mathrm{KY} 14$ and $444 \mathrm{Ph} / \mathrm{Php}$ testcross progenies from [DH92-2770-40 $\times$ NC1071] $\times$ DH94-1577-1 were evaluated in randomized complete block (RCB) design experiments in black shank nurseries at the Upper Coastal Plain Research Station at Rocky Mount, NC, in 1997. Each RCB consisted of 22-plant plots containing parental lines TG 593-13, L8, NC 1071, and DH92-2770-40 as resistant checks, testers KY 14 and DH94-1577-1 as susceptible checks replicated twice, and the testcross progenies.

The experiments were bordered by the black shank susceptible cultivar Hicks to monitor and maintain the activity of $P$. parasitica var. nicotianae in the tests. Black shank was assessed biweekly with individual plants rated as resistant if there was no sign of disease at the final disease reading, 98 days after transplanting as previously described (6). Transplant and cultural practices were those used in conventional tobacco production. Allelism was determined by $\chi^{2}$ analyses.

Greenhouse tests to confirm field results. In the field, black shank symptoms are caused primarily by race 0 of $P$. parasitica var. nicotianae, but occasionally race
1 can also cause similar disease symptoms. Therefore, greenhouse root inoculations of $200 \mathrm{Ph} / \mathrm{Phl}$ testcross plants and four plants each of TG 593-13, L8, the $\mathrm{F}_{1}$ hybrid (TG $593-13 \times \mathrm{L} 8$ ), and KY 14 were performed to confirm that plants lost in the field to black shank were infected with $P$. parasitica var. nicotianae race 0 . Plants were transplanted into MetroMix 200 sterile medium in square $8.5-\mathrm{cm}$ plastic pots and grown under an 18-h photoperiod for 3 weeks at $26^{\circ} \mathrm{C}$ in a growth room. The plants were moved to a greenhouse 1 week prior to inoculation.

Inoculum preparation and disease evaluation. Pure cultures of $P$. parasitica var. nicotianae race 0 were grown on $5 \%$ oatmeal agar in $100 \times 20 \mathrm{~mm}$ petri plates for 2 weeks in the dark at room temperature. The mycelia and agar medium of 15 plates were added to 1 liter of deionized water, homogenized in a Waring Blender for $30 \mathrm{~s}$, and kept on ice until needed. Prior to inoculation, plants were fertilized (20-2020) and irrigated to saturation. Two holes, 1 $\mathrm{cm}$ in diameter and 4 to $5 \mathrm{~cm}$ deep, were made on each side of the plant in a pot, and $10 \mathrm{ml}$ of the $P$. parasitica var. nicotianae race 0 inoculum was poured into each hole. Holes were filled with surrounding soil to prevent dehydration of the inoculum. Disease development was monitored daily for 2 weeks, beginning 3 days following inoculation. Plants were rated resistant if they showed no symptoms and susceptible if death occurred from black shank.

Cladistic analyses for $\boldsymbol{P h}$ from Coker 371-G. DNA was extracted and standard-

Table 1. Operon (OP) and University of British Columbia (UBC) decamer primers generating random amplified polymorphic DNA (RAPD) markers linked to the $P h$ gene from tobacco cultivar Coker $371-G^{\mathrm{a}}$

\begin{tabular}{|c|c|c|c|c|c|}
\hline RAPD & $\underset{\text { program }^{\mathrm{b}}}{\text { Amplification }}$ & RAPD & $\begin{array}{c}\text { Amplification } \\
\text { program }\end{array}$ & RAPD & $\begin{array}{c}\text { Amplification } \\
\text { program }\end{array}$ \\
\hline OPB- $13_{1040^{c}}$ & 2 & OPAJ- $12_{535}$ & 2 & UBC- $265_{1010}$ & 2 \\
\hline OPZ-7 $770^{\mathrm{c}}$ & 1 & OPAJ- $15_{535}$ & 2 & UBC- $296_{300}$ & 1 \\
\hline UPC- $365_{565}{ }^{\mathrm{c}}$ & 2 & OPAK- $18_{645}$ & 2 & UBC- 297400 & 1 \\
\hline UBC- $484_{600}{ }^{c}$ & 2 & OPAL- $14_{300}$ & 1 & UBC- $333_{270}$ & 1 \\
\hline UBC-671 $1230^{c}$ & 2 & OPAN- 2760 & 2 & UBC- $387_{1000}$ & 1 \\
\hline OPE- $10_{430}$ & 1 & OPAN-9 900 & 2 & UBC-412600 & 2 \\
\hline OPH- $18_{430}$ & 2 & UBC- $30_{490}$ & 2 & UBC- 422420 & 2 \\
\hline OPM- $16_{250}$ & 1 & UBC $159_{590}$ & 2 & UBC- 427575 & 2 \\
\hline OPN- $8_{440}$ & 3 & UBC- $162_{400}$ & 2 & UBC- $-443_{360}$ & 2 \\
\hline OPR- $1_{1160}$ & 1 & UBC- $171_{400}$ & 1 & UBC- $443_{560}$ & 2 \\
\hline OPR-7 600 & 2 & UBC- $183_{900}$ & 1 & UBC447 564 & 2 \\
\hline OPU-9 & 2 & UBC- $184_{800}$ & 1 & UBC- $469_{385}$ & 2 \\
\hline OPW- $3_{410}$ & 2 & UBC- $227_{950}$ & 1 & UBC- $564_{345}$ & 2 \\
\hline OPZ-5 & 1 & UBC- $247_{570}$ & 2 & UBC-571 800 & 2 \\
\hline OPAD- $3_{710}$ & 2 & UBC- $248_{430}$ & 1 & UBC- $613_{640}$ & 2 \\
\hline OPAE- $5_{2100}$ & 1 & UBC- $259_{600}$ & 1 & UBC- $664_{831}$ & 2 \\
\hline
\end{tabular}

${ }^{a}$ Standard errors of \pm 12 bp for RAPD fragment size were estimated using the "shareware" package Seqaid (22).

${ }^{\text {b }}$ Amplification programs used to generate the RAPD markers: Program 1: 1 cycle $94^{\circ} \mathrm{C} / 30 \mathrm{~s} ; 3$ cycles $94^{\circ} \mathrm{C} / 1 \mathrm{~min}, 38^{\circ} \mathrm{C} / 1 \mathrm{~min}, 72^{\circ} \mathrm{C} / 2 \mathrm{~min} ; 35$ cycles $92^{\circ} \mathrm{C} / 1 \mathrm{~min}, 40^{\circ} \mathrm{C} / 1 \mathrm{~min}, 72^{\circ} \mathrm{C} / 2 \mathrm{~min}+1 \mathrm{~s}$ extension/cycle; 1 cycle $72^{\circ} \mathrm{C} / 5 \mathrm{~min}$. Program 2: 1 cycle $94^{\circ} \mathrm{C} / 30 \mathrm{~s} ; 3$ cycles $94^{\circ} \mathrm{C} / 1 \mathrm{~min}, 38^{\circ} \mathrm{C} / 1$ min, $72^{\circ} \mathrm{C} / 2 \mathrm{~min} ; 35$ cycles $92^{\circ} \mathrm{C} / 10 \mathrm{~s}, 40^{\circ} \mathrm{C} / 20 \mathrm{~s}, 72^{\circ} \mathrm{C} / 2 \mathrm{~min}+1 \mathrm{~s}$ extension $/$ cycle; 1 cycle $72^{\circ} \mathrm{C} / 5$ min. Program 3: 1 cycle $94^{\circ} \mathrm{C} / 1 \mathrm{~min} ; 15$ cycles $92^{\circ} \mathrm{C} / 30 \mathrm{~s}, 50^{\circ} \mathrm{C} / 30 \mathrm{~s}$ minus $0.5^{\circ} \mathrm{C} /$ cycle, $72^{\circ} \mathrm{C} / 2 \mathrm{~min} ; 20$ cycles $92^{\circ} \mathrm{C} / 10 \mathrm{~s}, 40^{\circ} \mathrm{C} / 20 \mathrm{~s}, 72^{\circ} \mathrm{C} / 2 \mathrm{~min}+1 \mathrm{~s}$ extension/cycle; 1 cycle $72^{\circ} \mathrm{C} / 5$ $\min$.

${ }^{c}$ RAPD markers in repulsion-phase linkage with the $P h$ gene. All other RAPD markers are in coupling-phase linkage with $P h$.

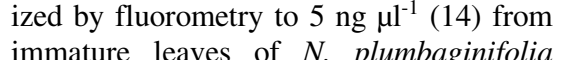
accessions TW 106 and TW 108, N. longiflora (brevifolia) accessions TW 79 accessions TW 78 and TW 81, tobacco lines DH92-2770-40, NC 1071, and culti139, and Hicks. Random amplified polymorphic DNA (RAPD) analyses were perOperon Technologies (Alameda, CA) and couver, Canada). These primers generated 43 RAPD markers in coupling- and 5 in RAPD amplifications were performed using each of the 48 primers in $15-\mu l$ tained $15 \mathrm{ng}$ of genomic DNA, $10 \mathrm{mM}$ Stoffel buffer), $200 \mu \mathrm{M}$ of each dNTP, 1 unit of AmpliTaq DNA polymerase Stoffel

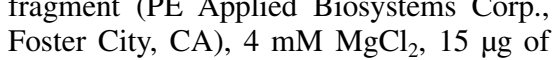
bovine serum albumin (Sigma Chemical decamer primer. For a primer control, template DNA was replaced with sterile water $50 \mu \mathrm{l}$ of sterile mineral oil (Sigma).

well PTC 100 thermal cycler (MJ Research, Watertown, MA); the temperature primer (Table 1). Amplified products were separated for $6 \mathrm{~h}$ at $3 \mathrm{~V} / \mathrm{cm}$ constant voltage in $1.5 \%$ cold $\left(4^{\circ} \mathrm{C}\right.$ overnight $)$ agarose 
gels (Sigma) containing $0.15 \mu \mathrm{g}$ of ethidium bromide per liter. Submerged gel electrophoresis was performed in $1 \times \mathrm{TBE}$ buffer $(0.09 \mathrm{M}$ Tris borate, $0.002 \mathrm{M}$ EDTA) (23) containing $0.046 \mu \mathrm{g}$ of ethidium bromide per liter. One lane on each gel contained a 100-bp DNA Ladder (Gibco BRL, Life Technologies, Grand Island, NY).

RAPD marker distribution was used to study the relationships among the three Nicotiana species. Parsimony analyses were performed using the program PAUP (10) to produce a region or gene tree for $P h$.

Determination of genetic recombination in $\boldsymbol{P h} / \boldsymbol{P h l}$ hybrids by RAPD analyses. Six RAPD markers in coupling-phase linkage to $P h, \quad \mathrm{OPN}-8_{440}, \mathrm{UBC}-30_{490}$, UBC-159 $9_{590}$, UBC-248 430 , UBC-427 575 , and UBC-469 $9_{385}$, were present only in C 371-G, DH92-2770-40, NC 1071, and the two N. plumbaginifolia accessions. Subsequent to root inoculations, DNA was extracted from disease-free plants of 16 TG 593-13 $\times \mathrm{L} 8(\mathrm{Ph} / \mathrm{Phl})$ testcross progenies, TG 593-13, the TG 593-13 × L8 hybrid,

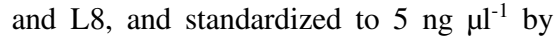
fluorometry. RAPD amplifications using each of the six decamer primers separately and product separation were conducted as previously described.

\section{RESULTS}

Field and greenhouse black shank evaluations of testcross progenies. Seven plants were lost to black shank from 440 $\mathrm{Ph} / \mathrm{Phl}$ testcross progenies evaluated in the field disease nursery. Inoculum level in the black shank nursery was high, as the susceptible check and tester KY 14 only survived an average of 48.5 days (100\% disease incidence [DI]) after transplanting. All plants of the parental lines TG 593-13 and L8 survived the full season (98 days, 0\% DI). One plant of the hybrid TG 593-13 $\times$ L8 was lost to disease.

One plant was lost to black shank from the $444 P h / P h p$ testcross. The susceptible check and tester DH94-1577-1 survived an average of 84 days in the black shank nursery. No plants were lost from the parental lines NC 1071 and DH92-2770-40 or their $\mathrm{F}_{1}$ hybrid. Map distance between $P h$ and $P h l$ was estimated by linkage and $\chi^{2}$ analyses at $3.18 \mathrm{cM}(P<0.005)$. Thus, $P h$ and Php were determined to be allelic (Table 2).

Table 2. Linkage relationships between $P h$ from Coker 371-Gold, Phl from Nicotiana longiflora, and Php from Nicotiana plumbaginifolia ${ }^{\mathrm{a}}$

\begin{tabular}{|c|c|c|c|c|}
\hline $\begin{array}{l}\text { Black shank } \\
\text { R gene }\end{array}$ & $\frac{\text { Observed frequencies }}{\mathbf{R}: \mathbf{S}^{\mathbf{b}}}$ & $\chi^{2}$ & $P$ & $\begin{array}{l}\text { Estimated linkage } \\
\text { distance }(\mathrm{cM})\end{array}$ \\
\hline$P h$ and $P h l^{\mathrm{c}}$ & $433: 7$ & 128.58 & 0.00 & 3.18 \\
\hline$P h$ and $P h p$ & $443: 1$ & 145.35 & 0.00 & 0.45 \\
\hline$P h$ and $P h l^{\mathrm{d}}$ & $197: 3$ & 58.91 & 0.00 & 3.00 \\
\hline
\end{tabular}

${ }^{a} \chi^{2}$ values for goodness-of-fit to expected ratios were calculated for field data from the Upper Coastal Plain Research Station, Rocky Mount, NC, in 1997 and for greenhouse root inoculation trials in 1998.

${ }^{\text {b }}$ A 3 resistant:1 susceptible ratio is expected if the two loci are segregating independently. Expected genotypic frequencies are 1/4 PhPhl/phphl: 1/4 Phphl/phphl: 1/4 phPhl/phphl:1/4 phphl/phphl.

c Testcross progenies from TG 593-13 $\times$ L8 evaluated in the field.

${ }^{d}$ Testcross progeny of TG 593-13 evaluated in the greenhouse.
Root inoculations performed in the greenhouse with race 0 of $P$. parasitica var. nicotianae corroborated field observations for the $P h / P h l$ testcross progeny of TG 593-13 × L8. Typical black shank symptoms were observed on KY 14, the susceptible check, 3 days postinoculation. All inoculated KY 14 plants were dead from black shank within 5 days after root inoculation. Three of 200 testcross progenies were lost to black shank 5 to 10 days after inoculation (Table 2). No plants were lost from TG 593-13, TG 593-13 × L8, and L8 from root black shank infections.

Genetic recombination in $\mathrm{Ph} / \mathrm{Phl}$ hybrids visualized by RAPD analyses. RAPD analyses on the 16 testcross plants using the six RAPD markers, OPN- $8_{440}$, UBC- $30_{490}$, UBC- $159_{590}$, UBC- $248_{430}$, UBC-427 575 , and UBC-469 385 , in couplingphase linkage to $P h$ further support the hypothesis that the three plants lost to black shank could have resulted from genetic recombination events. Crossing over occurred within and around the region containing the six RAPDs, resulting in partial to complete loss of the markers while resistance was maintained (Table 3 ). The three black shank-susceptible testcross plants were not available for RAPD analyses; however, at least eight recombination events occurred between the $P h$ and $P h l$ segments present in the 16 testcross progenies analyzed (Table 3). Thus $P h$ and $P h l$ are not allelic, and recombination can occur between the loci to generate genotypes susceptible to black shank.

Cladistic analyses. The 48 RAPD markers, 43 in coupling- and five in repulsion-phase linkage to the $P h$ locus, proved to be cladistically informative. Polymorphisms generated by the RAPD markers (Fig. 1) could be separated into 11 unique banding types in the three Nicotiana species and were used in cluster analyses to

Table 3. Recombination of six random amplified polymorphic DNA (RAPD) markers in black shank root resistant $P h / P h l$ testcross progenies ${ }^{\mathrm{a}}$

\begin{tabular}{|c|c|c|c|c|c|c|c|}
\hline Genotype & $\begin{array}{c}\text { Disease } \\
\text { reaction }\end{array}$ & OPN-8 ${ }_{440}^{b}$ & UBC-159 590 & $\mathrm{UBC}^{-427_{575}}$ & UBC-469 385 & UBC- $248_{430}$ & $\mathrm{UBC}^{-30_{490}}$ \\
\hline L8 & $\mathrm{R}$ & $0^{\mathrm{c}}$ & 0 & 0 & 0 & 0 & 0 \\
\hline TG 593-13 & $\mathrm{R}$ & 1 & 1 & 1 & 1 & 1 & 1 \\
\hline TG 593-13 × L8 & $\mathrm{R}$ & 1 & 1 & 1 & 1 & 1 & 1 \\
\hline [TG 593-13 × L8] $\times$ KY 14 & $\mathrm{R}$ & 1 & 1 & 1 & 1 & 1 & 1 \\
\hline [TG 593-13 × L8] × KY 14 & $\mathrm{R}$ & 1 & 1 & 1 & 1 & 1 & 1 \\
\hline [TG 593-13 × L8] $\times \mathrm{KY} 14$ & $\mathrm{R}$ & 1 & 1 & 1 & 1 & 1 & 1 \\
\hline [TG 593-13 × L8] × KY 14 & $\mathrm{R}$ & 1 & 1 & 1 & 1 & 1 & 1 \\
\hline$[$ TG $593-13 \times$ L8] $\times$ KY 14 & $\mathrm{R}$ & 1 & 1 & 1 & 1 & 1 & 1 \\
\hline [TG 593-13 × L81 × KY 14 & $\mathrm{R}$ & 1 & 1 & 1 & 1 & 1 & 1 \\
\hline [TG 593-13 × L8] $\times$ KY 14 & $\mathrm{R}$ & 1 & 1 & 1 & 1 & 1 & 1 \\
\hline [TG 593-13 × L8] $\times$ KY 14 & $\mathrm{R}$ & 0 & 0 & 0 & 0 & 0 & 0 \\
\hline [TG 593-13 × L81 × KY 14 & $\mathrm{R}$ & 0 & 0 & 0 & 0 & 0 & 0 \\
\hline [TG $593-13 \times$ L8] $\times$ KY 14 & $\mathrm{R}$ & 0 & 0 & 0 & 0 & 0 & 0 \\
\hline [TG 593-13 × L81 × KY 14 & $\mathrm{R}$ & 0 & 0 & 0 & 0 & 0 & 0 \\
\hline [TG 593-13 × L8] × KY 14 & $\mathrm{R}$ & 0 & 0 & 0 & 0 & 0 & 0 \\
\hline [TG 593-13 × L8] $\times$ KY 14 & $\mathrm{R}$ & 0 & 0 & 0 & 0 & 0 & 0 \\
\hline [TG 593-13 × L8] × KY 14 & $\mathrm{R}$ & 1 & 1 & 1 & 0 & 0 & 1 \\
\hline [TG 593-13 × L8] $\times \mathrm{KY} 14$ & $\mathrm{R}$ & 1 & 1 & 1 & 1 & 1 & 1 \\
\hline [TG 593-13 × L8] × KY 14 & $\mathrm{R}$ & 1 & 1 & 1 & 1 & 0 & 1 \\
\hline
\end{tabular}

${ }^{\text {a }}$ Crossing over between the $P h$ and $P h l$ segments is apparent as some progenies have lost some or all of the RAPD markers.

${ }^{b}$ RAPD fragment, size $440 \mathrm{bp}$, generated by Operon primer N-8. Primers from the University of British Columbia are abbreviated UBC.

${ }^{c}$ Indicates presence (1) or absence (0) of RAPD fragment. 
generate a region or gene tree for $\mathrm{Ph}$ (Fig. 2). This is one of the best three that fit the RAPD data, trees varying only in the ranking of genotypes within a branch. The data from RAPD and cladistic analyses showed that the region containing $P h$ from $\mathrm{C}$ 371Gold is more closely related to $N$. plumbaginifolia and NC 1071 than L8, any of the $N$. longiflora accessions or the ancestral N. tabacum lines tested (Fig. 2).

\section{DISCUSSION}

The homology of the dominant black shank resistance genes $P h p$ and $P h l$ from $N$. plumbaginifolia and $N$. longiflora, respectively, has long been debated $(1,8,15)$. Here we present field, greenhouse, and RAPD data which show that $P h$ from $C$ 371-G is allelic to $P h p$ from N. plumbaginifolia in NC 1071. Conversely, $P h p$ and $P h$ are not allelic, but homologous in function to $P h l$ in breeding line L8 developed from the closely related species $N$. longiflora.

Testcross populations from $\mathrm{Ph} / \mathrm{Phl}$ hybrids were designed so that confounding effects of Fla 301 black shank resistance would be negligible. Black shank resistance in the burley breeding line TG 59313 is mediated by the $P h$ gene from C 371 G. Testcross, rather than selfed populations from the hybrid TG 593-13 × L8, were used to maximize the probability of finding susceptible, double recessive genotypes if the $P h$ and $P h l$ genes were not allelic. Susceptible recombinants were observed at low frequencies in both greenhouse and field disease trials.

$\mathrm{F}_{1}$ hybrids of DH92-2770-40 $\times$ NC 1071 did not produce gametes lacking a dominant allele for black shank resistance. We conclude, therefore, that the $P h$ gene in DH92-2770-40, from C 371-G, is allelic to Php from NC 1071. Field trials with the $P h / P h l$ testcross progenies showed that susceptible genotypes were produced at a frequency of approximately $1.5 \%$. This frequency would represent one-half of the recombination events between the two loci. Hence, $P h$ and $P h l$ appear to be linked approximately $3 \mathrm{cM}$ apart.

These data also explain the results of a study of the relationship between the black shank resistance genes in $N$. plumbaginifolia and N. longiflora conducted in 1971 (8). These authors observed one susceptible recombinant in an $\mathrm{F}_{2}$ population of 4,810 individuals from a cross between two segmental substitution lines containing black shank resistance from $N$. plumbaginifolia and $N$. longiflora, respectively. If the $P h$ and $P h l$ loci are $3 \mathrm{cM}$ apart, as estimated in our study, then the probability of obtaining a double recessive recombinant in an $\mathrm{F}_{2}$ population would be $2.25 \times 10^{-4}$, or 1 in 5,000 . As this is such a rare occurrence, the authors dismissed their findings and declared the two black shank resistance loci homologous (8).

Black shank susceptible recombinant gametes could arise in the $P h / P h l$ testcross progenies by either recombination or loss of the chromosomal segments carrying the resistance genes. Proof that the double recessive gamete arose from recombination events could be ascertained if other recombination events were observed between the $P h$ and $P h l$ segments in the tobacco genome. In tobacco, recombination is greatly suppressed between hybrids containing an interspecific chromosomal segment and its heterolog in the tobacco genome $(3,11)$. Six RAPD markers, which distinguish the $P h$ and $P h l$ introgressed regions in the three Nicotiana species, recombined with at least 8 crossover events occurring in 16 plants tested from $\mathrm{Ph} / \mathrm{Phl}$ testcross progenies. Since the RAPD markers are recombining in resistant testcross progenies, we conclude that double recessive genotypes most likely arose by recombination events.

Data from field and greenhouse disease trials showed that $P h$ and $P h l$ are different genes with homologous function. Thus, cladistic analyses could be used to further study the relationship between the introgressed regions containing these genes. A cladogram or gene tree for $P h$ generated from 48 RAPD markers linked to the region containing the gene supported field and greenhouse data. The cladogram generated by parsimony analyses, an algorithm using the least number of character changes to explain the data $(10,19)$, depicted shared similarities between the three Nicotiana species for the region containing the $P h$ gene from C 371-G. Genotypes in close proximity are more closely related to each other, with respect to $P h$, than those further apart on the tree. By definition, cladograms do not reflect ancestral relationships (10). This analysis confirmed that the region containing $P h$ in $\mathrm{C} 371-\mathrm{G}$ is more closely related to that of $P h p$ in NC 1071, from N. plumbaginifolia, and different from the $P h l$ region derived from $N$. longiflora.

Since $P h$ and $P h l$ integrated in close proximity in the $N$. tabacum genome, they exhibit clustering characteristic of other resistance loci. Extensive research into the structure, function, and origin of cloned plant disease resistance genes is currently under way. Dominant resistance genes, such as $P h$ or $P h l$, effective against hemibiotrophs such as $P$. parasitica var. nicotianae and involved in signal transduction and activation of the HR, have been found to occur in clusters of either allelic or closely related genes $(4,21)$. Four arrangements of resistance loci, two of which may be applicable to $P h$ and $P h l$, have been described (13). They may be members of a complex resistance locus comprised of tandem arrays of closely linked resistance gene homologues with differing

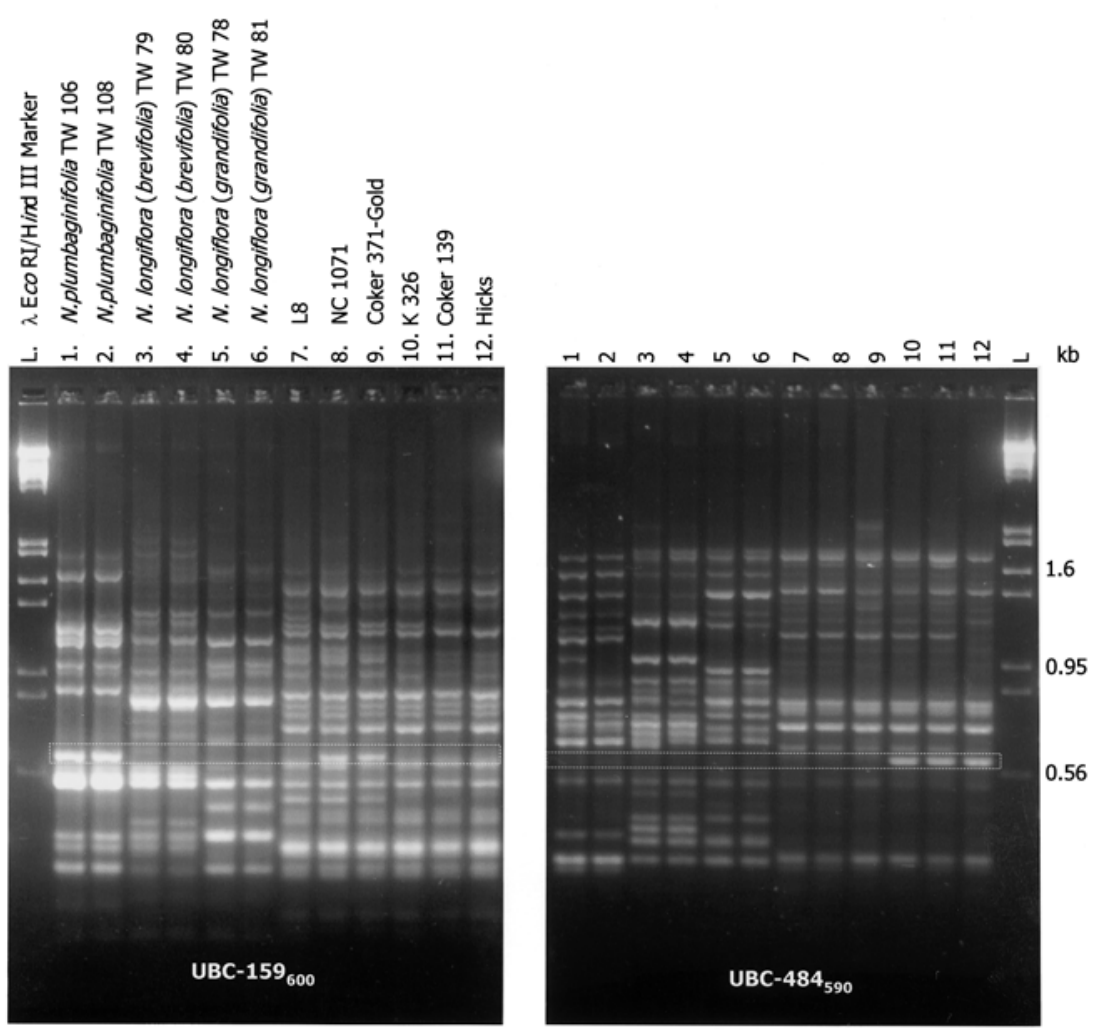

Fig. 1. Banding patterns of the cladistically informative random amplified polymorphic DNA (RAPD) markers UBC-159 $9_{600}$ linked in coupling-phase, and UBC-484 590 linked in repulsion-phase to $P h$. Banding patterns of the RAPD markers in the three Nicotiana species were analyzed to determine the origin of $P h$ from Coker 371-Gold. Amplification products (15 $\mu l)$ were separated on $1.5 \%$ agarose gels. RAPD marker size has a standard deviation of $\pm 9 \mathrm{bp}$. 


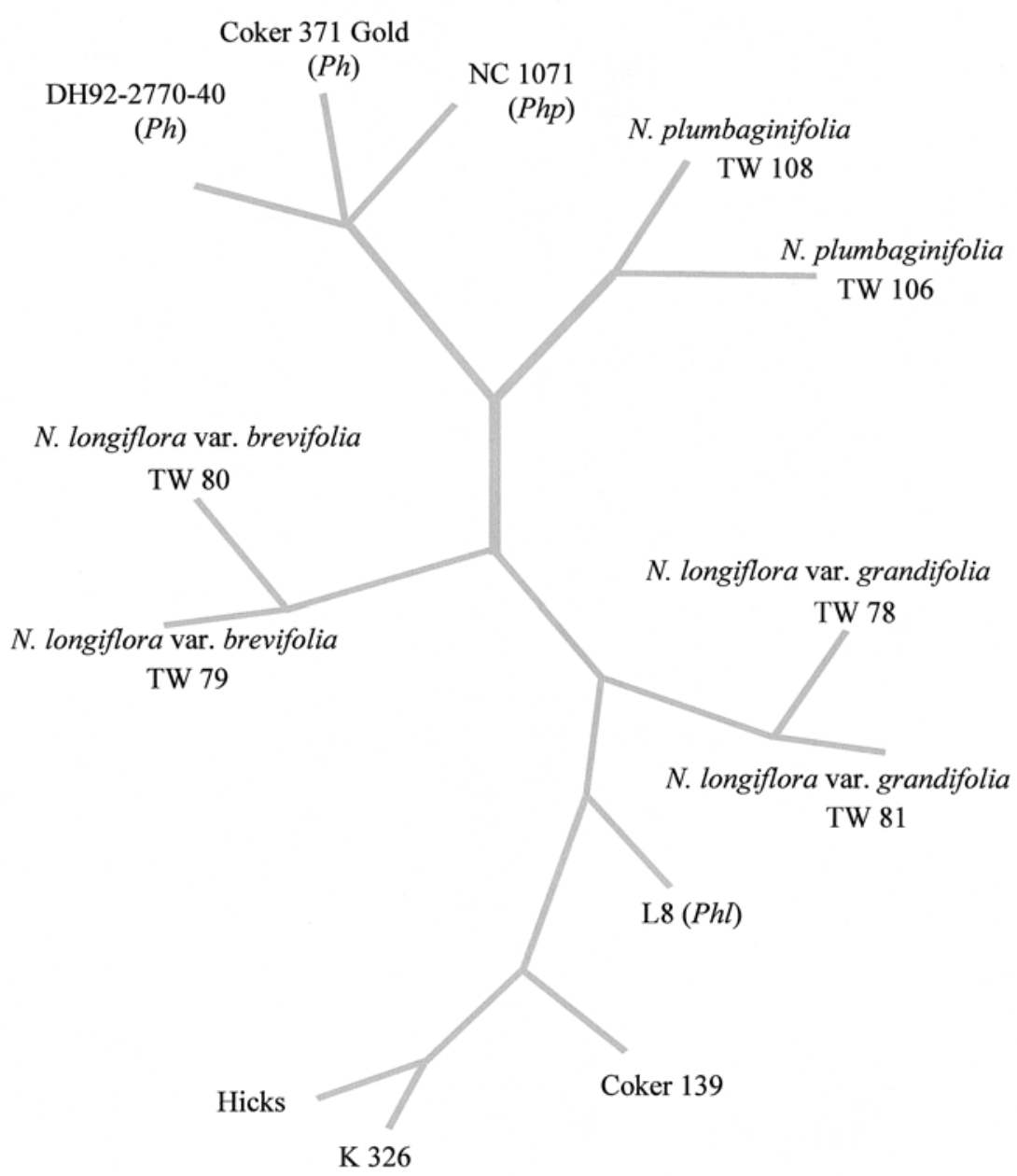

Fig. 2. One of three most parsimonious cladograms based on random amplified polymorphic DNA (RAPD) polymorphisms between the predecessors of Coker 371-Gold and the three Nicotiana species for the region containing the $P h$ gene.

specificities. Alternatively, $P h$ and $P h l$ may be members of a major resistance complex such as the region on chromosome 6 in tomato which contains resistance genes $C f$ 2/-5 to Cladosporium fulvum, Mi to Meloidogyne spp., and Meu to Macrosiphum euphorbiae (17). Linkage between bacterial wilt and black shank resistance has been reported (25). Cloning of $P h$ and $P h l$ genes will provide the information needed to classify these resistance loci.

\section{ACKNOWLEDGMENTS}

We gratefully acknowledge Kurt Wollenberg, Department of Genetics, NCSU, for performing parsimony analyses. We also thank John Tysinger, Todd Campbell, Lori Linger, Ramsey Lewis, and Susana Milla for assisting with fieldwork and data collection. The authors wish to thank Verne Sisson, Oxford Tobacco Research Station, Oxford, $\mathrm{NC}$, for kindly providing seed of $N$. plumbaginifolia and $N$. longiflora accessions. This work was funded by Philip Morris USA and the North Carolina Tobacco Research Commission.

\section{LITERATURE CITED}

1. Apple, J. L. 1962. Physiological specialization within Phytophthora parasitica var. nicotianae. Phytopathology 52:351-354.
2. Apple, J. L. 1967. Occurrence of race 1 of Phytophthora parasitica var. nicotianae in North Carolina and its importance in breeding for disease resistance. Tob. Sci. 11:79-83.

3. Bai, D., Reeleder, R. and Brandle, J. E. 1995. Identification of two RAPD markers tightly linked with the Nicotiana debneyi gene for resistance to black root rot of tobacco. Theor. Appl. Genet. 91:1184-1189.

4. Bennetzen, J. L., and Hulbert, S. H. 1992. Extramarital sex amongst the beets - Organization, instability and evolution of plant disease resistance genes. Plant Mol. Biol. 20:575-580.

5. Bowman, D. T., Wernsman, E. A., Corbin, T. C., and Tart, A. G. 1984. Contribution of genetics and production technology to long-term yield and quality gains in flue-cured tobacco. Tob. Sci. 28:30-35.

6. Carlson, S. R., Wolff, M. F., Shew, H. D., and Wernsman, E. A. 1997. Inheritance of resistance to race 0 of Phytophthora parasitica var. nicotianae from the flue-cured tobacco cultivar Coker 371-Gold. Plant Dis. 81:12691274.

7. Chaplin, J. F. 1962. Transfer of black shank resistance from Nicotiana plumbaginifolia to flue-cured $N$. tabacum. Tob. Sci. 6:184-189.

8. Collins, G. B., Legg, P. D., Litton, C. C., and Stokes, G. W. 1971. Locus homology in two species of Nicotiana. J. Hered. 62:288-290.
9. Csinos, A. S., and Bertrand, P. F. 1994. Distribution of Phytophthora parasitica var. nicotianae races and their sensitivity to metalaxyl in Georgia. Plant Dis. 78:471-474.

10. Fitch, W. M. 1971. Toward defining the course of evolution: Minimum change for a specified tree topology. Syst. Zool. 20:406416.

11. Gerstel, D. U., and Burk, L. G. 1960. Controlled introgression in Nicotiana: A cytological study. Tob. Sci. 4:147-150.

12. Goins, R. B., and Apple, J. L. 1970. Inheritance and phenotypic expression of a dominant factor for black shank resistance from Nicotiana plumbaginifolia in a Nicotiana tabacum milieu. Tob. Sci. 14:7-11.

13. Hammond-Kosack, K. E., and Jones, J. D. G. 1997. Plant disease resistance genes. Annu. Rev. Plant Physiol. Plant Mol. Biol. 48:575 607.

14. Johnson, E., Miklas, P. N., Stavely, J. R., and Martinez-Cruzado, J. C. 1995. Coupling- and repulsion-phase RAPDs for marker-assisted selction of PI 181996 rust resistance in common bean. Theor. Appl. Genet. 90:659-664.

15. Litton, C. C., Collins, G. B., and Legg, P. D 1970. Reaction of Nicotiana tabacum and other $N$. species to race 0 and 1 of $P h y$ tophthora parasitica var. nicotianae. Tob. Sci. 14:128-130.

16. Lucas, G. B. 1975. Black shank. Pages 115 141 in: Diseases of Tobacco. 3rd ed. Harold E. Parker \& Sons Printers, Farquay-Varina, NC.

17. Martin, G. 1996. Molecular cloning of plant disease resistance genes. Pages 1-32 in: PlantMicrobe Interactions Vol. 1. G. Stacey and N T. Keen, eds. Chapman \& Hall, London.

18. McIntyre, J. L., and Taylor, G. S. 1978. Race 3 of Phytophthora parasitica var. nicotianae. Phytopathology 68:35-38.

19. Minelli, A. 1993. Biological Systematics. Chapman \& Hall, London.

20. Prinsloo, G. C., and Pauer, D. C. 1974. Die identikikasie van rasse van Phytophthora nicotianae B de Haan var. nicotianae wat in Suid-Afrika voorkom. Phytophylactica 6:217220.

21. Pryor, T., and Ellis, J. 1993. The genetic complexity of fungal resistance genes in plants. Adv. Plant Pathol. 10:281-305.

22. Rhoads, D. D., and Roufa, D. J. 1990 SEQAID II Version 3.8. Kansas State University, Manhattan. IUBio Archive. Published on-line.

23. Sambrook, J., Fitsch, E. F., and Maniatis, T. 1989. Molecular Cloning: A Laboratory Manual. Cold Spring Harbor Laboratory, Cold Spring Harbor, NY

24. Shenoi, M. M., Abdul Wajid, S. M., Elias, N. A., and Bhaktavatsalam, G. 1985. Occurrence of a new race of Phytophthora nicotianae var. parasitica in Hunsur tract. Ind. Phytopathol. 38:537-539.

25. Smith, T. E., and Clayton, E. E. 1948. Resistance to bacterial wilt and black shank in fluecured tobacco. Phytopathology 38:227-229.

26. Valleau, W. D., Stokes, G. W., and Johnson, E. M. 1960. Nine years' experience with the Nicotiana longiflora factor for resistance to Phytophthora parasitica var. nicotianae in the control of black shank. Tob. Sci. 4:92-94.

27. Wernsman, E. A., Matzinger, D. F., and Powell, N. T. 1974. Genetic investigations of intraspecific and interspecific sources of black shank resistance in tobacco. Tob. Sci. 18:15 18.

28. Williams, J. G. K., Kubelik, A. R., Livak, K. J., Rafalski, J. A., and Tingey, S. V. 1990. DNA polymorphisms amplified by arbitrary primers are useful as genetic markers. Nucleic Acids Res. 18:6531-6535. 